\title{
EVALUATION OF PAPAYA NECTAR PREPARED FROM UNPEELED PAPAYA PUREE ${ }^{1}$
}

Preparation of papaya purees from peeled fruit has been reported by other investigators. Stafford et $\mathrm{al}^{2}$ describe a procedure for preparing a puree from peeled papayas of the Solo variety grown in Hawaii.

This note reports data evaluating papaya nectars prepared from unpeeled papaya purees. The fruit used in these experiments was from commercial varieties grown at the Gurabo Substation.

\section{PULP EXTRACTION}

The papayas were harvested when mature-green, then ripened at room temperature spontaneously. The ripe papayas were sorted, washed with brushes, trimmed, cut into halves and the seeds were removed by hand. Unpeeled fruit sections were further cut into smaller pieces and mashed in a comminuting mill using a No. 4 screen. The mashed fruit was then fed by gravity into a Langzenkamp paddle pulper fitted with a 0.060 -inch screen. The pulp was transferred to a paddle finisher equipped with a 0.033inch screen. After the finishing operation, 17.5-percent sugar per weight of pulp was added to inhibit gelation. ${ }^{3}$ The mixture then was heated in a Votator at $190^{\circ} \mathrm{F}\left(87.8^{\circ} \mathrm{C}\right.$.), canned in No. 10 enameled cans and frozen at $-10^{\circ} \mathrm{F} .\left(-23.3^{\circ} \mathrm{C}.\right)$.

\section{NECTAR PREPARATION}

Nectar samples were prepared from the resulting frozen papaya pulp. The pulp was thawed and passed through a stone-mill with 0.006 -inch stone separation. Water was added to dilute to 33.3 percent-pulp content. ${ }^{4}$ Soluble solids were adjusted to $15^{\circ}$ Brix with sucrose. Citric acid was added to adjust the pH to 3.7. Nectar samples were flash-pasteurized in a Votator at $190^{\circ} \mathrm{F}$. $\left(87.8^{\circ} \mathrm{C}\right)$, canned in 8 -ounce enameled cans and stored at $85^{\circ} \mathrm{F}$. $\left(29.4^{\circ} \mathrm{C}\right.$.). Samples were evaluated periodically through chemical analyses and sensory appraisals during a 12-month storage period.

The data obtained from the chemical analyses of the papaya nectars are presented in table 1 . The results indicate that the chemical composition of

1 Manuscript submitted to the Editorial Board July 9, 1971.

2 Stafford, A. E., Cavaletto, C. G., and Brekke, J. E., Papaya puree processing, Hawaii Agr. Exp. Sta., Tech. Progr. Rep. No. 157, 3-7, 1966.

3 Yamamoto, H. Y. and Inouye, W., Sucrose as a gelation inhibitor of commercially frozen papaya puree, Hawaii Agr. Exp. Sta., Tech. Progr. Rep. No. 137, 1963.

4 U.S. Department of Health, Education, and Welfare, Food and Drug Administration, Federal Register, 1964. 
TABLE 1.-Chemical composition of papaya nectar samples during a year of storage al $85^{\circ} \mathrm{F} .\left(29.4^{\circ} \mathrm{C}\right.$.)

\begin{tabular}{|c|c|c|c|c|c|c|c|c|c|c|c|c|c|}
\hline \multirow{3}{*}{ Item } & \multirow{3}{*}{ Units } & \multicolumn{12}{|c|}{ Months of storage } \\
\hline & & \multicolumn{3}{|c|}{$1 / 2$} & \multicolumn{3}{|c|}{4} & \multicolumn{3}{|c|}{8} & \multicolumn{3}{|c|}{12} \\
\hline & & Mean & $\begin{array}{l}\text { Mini- } \\
\text { mum } \\
\text { value }\end{array}$ & $\begin{array}{c}\text { Maxi- } \\
\text { mum } \\
\text { value }\end{array}$ & Mean & $\begin{array}{l}\text { Mini- } \\
\text { mum } \\
\text { value }\end{array}$ & $\begin{array}{c}\text { Maxi- } \\
\text { mum } \\
\text { value }\end{array} \mid$ & Mean & $\begin{array}{l}\text { Mini- } \\
\text { mum } \\
\text { value }\end{array}$ & $\begin{array}{l}\text { Maxi- } \\
\text { mum } \\
\text { value }\end{array}$ & Mean & $\begin{array}{l}\text { Mini- } \\
\text { mum } \\
\text { value }\end{array}$ & $\begin{array}{l}\text { Maxi- } \\
\text { mum } \\
\text { value }\end{array}$ \\
\hline Soluble solids & - Brix & 15.80 & 15.00 & 16.90 & 15.73 & 15.10 & 16.50 & 15.77 & 15.10 & 16.60 & 16.03 & 15.60 & 16.80 \\
\hline Vitamin C & $\begin{array}{l}\text { Mg./ } \\
100 \mathrm{~g} .\end{array}$ & 18.75 & 16.98 & 20.70 & 13.03 & 10.22 & 15.10 & 14.87 & 12.93 & 16.43 & 14.82 & 11.31 & 18.72 \\
\hline $\mathbf{p H}$ & & 3.71 & 3.65 & 3.74 & 3.70 & 3.64 & 3.72 & 3.73 & 3.67 & 3.79 & 3.65 & 3.58 & 3.70 \\
\hline $\begin{array}{l}\text { Acidity as anhy- } \\
\text { drous citric acid }\end{array}$ & $\begin{array}{l}\text { Per- } \\
\text { cent }\end{array}$ & .24 & .23 & .24 & .23 & .23 & .23 & .24 & .23 & .25 & .24 & .22 & .25 \\
\hline $\begin{array}{l}\text { Total sugars as in- } \\
\text { verts }\end{array}$ & Do. & 15.21 & 14.37 & 15.85 & 15.62 & 15.03 & 16.30 & 15.58 & 14.71 & 16.48 & 15.33 & 14.06 & 16.44 \\
\hline Reducing sugars & Do. & 8.57 & 8.02 & 8.85 & 10.19 & 8.38 & 11.24 & 12.87 & 12.17 & 13.52 & 13.10 & 12.38 & 13.55 \\
\hline $\begin{array}{l}\text { Reducing sugars/ } \\
\text { total sugars }\end{array}$ & Do. & 50.48 & 52.08 & 61.59 & 65.31 & 63.98 & 74.78 & 82.70 & 78.31 & 87.76 & 85.26 & 81.41 & 88.05 \\
\hline
\end{tabular}

the nectars did not undergo appreciable change throughout the storage period, although slight differences in the percentage of reducing sugars of the samples were detected. Taste appraisals of the nectars were made by a panel which rated the samples using a 9-point hedonic scale ${ }^{5}$ and the method of Kramer and Ditman, ${ }^{6}$ in which a $+2,-2$ or "acceptable-not acceptable" scale was used. The results showed that the overall quality of the samples was maintained at an acceptable level throughout the year of study.

Panel-testing information concerning consumer acceptance of unpeeled papaya nectar was obtained additionally, both locally and in the continental United States. Samples were distributed for evaluation to 130 persons on Visitor's Day at the Mayagüez Campus, University of Puerto Rico. Of these, 90 percent rated the samples as "acceptable" or "very acceptable." In acceptance tests conducted among 500 persons attending a convention of the U.S. Wholesaler Grocers Association, at Miami, Fla., 90 percent of the tasters also scored the samples "acceptable." Most of the tasters on the mainland detected a familiar apricot nectar flavor in the papaya nectar.

\section{A. J. Rodriguez \\ L. M. Iguina de George \\ Food Technology Laboratory}

- Peryam, D. R. and Pilgrim, F. J., Hedonic scale method of measuring food preferences, Food Tech. 11 (9): 9-14, 1957.

6 Kramer, A. and Ditman, L. P., A simplified variable taste panel method for detecting flavor changes in vegetables treated with pesticides, Food Tech. $10(3): 155-9$, 1956. 